\title{
CHANGES OF ANTIOXIDANT ACTIVITY DURING STORAGE OF WHEAT GRAINS WITH DIFFERENT COLOURS
}

\author{
V. B. KATRII ${ }^{1}$, K. V. LYSTVAN ${ }^{2}$, B. V. MORGUN ${ }^{1,2}$, N. V. SANDETSKA ${ }^{1}$, L. H. VELYKOZHON ${ }^{1,2}$ \\ ${ }^{1}$ Institute of Plant Physiology and Genetics of the NAS of Ukraine \\ Ukraine, 03022, Kyiv, Vasylkivska Str., 31/17 \\ 2 Institute of Cell Biology and Genetic Engineering of the NAS of Ukraine \\ Ukraine, 03143, Kyiv, Akademika Zabolotnoho Str., 148 \\ e-mail: katriy.vlad@gmail.com
}

\begin{abstract}
Aim. Evaluate the change in antioxidant activity $(A O A)$ during one-month storage period of flour and grist obtained by grinding wheat grains with different colours: white, red and purple. Wheat grain contains components with antioxidant activity. Over time AOA may be changed that is why it is important to investigate the dynamics of AOA changes in wheat samples with different grind flour and whole grain grist. Methods. The level of antioxidant activity of wheat flour spirituous extract and grist was determined based on their capacity to neutralize stable free radicals 2,2-diphenyl-1-picrylhydrazyl (DPPH). Results. Changes in level of antioxidant activity of cultivar "Bilyava» - white grain, "Kuyalnik» - red and "Chernozerna» - purple grain were investigated. Conclusions. Asymmetric distribution of components with antioxidant properties in wheat grains was observed. The purple grain cultivar demonstrated highest antioxidant activity the while white grain cultivar showed lowest antioxidant activity.
\end{abstract}

Keywords: colored grain, antioxidant activity, flour, grist.

Introduction. Herbal products such as cereals, fruits, vegetables, nuts are the main source of natural antioxidants in the human diet. Cereals are a leading source of unique fiber, minerals and antioxidants. Healthy diet key role belongs to cereals. Wheat is a staple food for the majority of the world's population (Liyana-Pathirana, Shahidi, 2005). In addition to being full of starch, proteins, minerals and dietary fiber, wheat is also a source of antioxidants such as flavonoids, phenolic acids, anthocyanins, which are anti-cancer and cardio protective agents.

Literature data have shown that many key biological functions, including antimutagenicity and anticarcinogenicity are associated with oxidative and antioxidative balance (Polishchuk et al., 2016). Antioxidants which neutralize reactive oxygen species and free radicals play a significant role in inhibition of oxidative mechanisms, which may trigger degenerative diseases (cancer, cardiovascular disease, cataracts, brain dysfunction, arthritis, etc. For humans endogenous antioxidants systems may not be sufficient to neutralize free radicals. That is why further oxidative damage of lipids proteins and nucleic acids may occur (Rice-Evans et al., 1997). Carotenoids, tocopherols, lignans, flavonoids and phenolic acid are antioxidant substances with low molecular weight and presented in wheat grains (Merike et al. 2010). Wheat antioxidants consumed with food by humans can react directly with reactive oxygen species, such as hydroxyl radicals or single oxygen molecules, to stop their attack on biological molecules. Antioxidants are considered to be able to neutralize free radicals and reduce oxidative damage (Blois, 1958). Antioxidant activity involves the removal of reactive oxygen species (ROS- ${ }_{2}^{-}, \mathrm{H}_{2} \mathrm{O}_{2}, \mathrm{RO}, \mathrm{ROO}, \mathrm{OH}, \mathrm{HOCl}$ ), reactive nitrogen species (RNS-NO, $\mathrm{ONOO}^{-}$), or reducing their effect on the body.

It was reported that the antioxidant activity of whole grain cereals, including whole grain bread, ranged from 1303 to $2479 \mu \mathrm{mol}$ is equivalent to trolox (TE) per $100 \mathrm{~g}$, while the mean values of 24 fruits and 22 vegetables were 2200 and $1200 \mu$ mol TE per $100 \mathrm{~g}$ respectively (Cook, Samman, 1996).

${ }^{\circ}$ V. B. KATRII, K. V. LYSTVAN, B. V. MORGUN, N. V. SANDETSKA, L. H. VELYKOZHON, 2020

ISSN 2415-3680 (Online), ISSN 1810-7834 (Print). Вісн. Укр. тов-ва генетиків і селекціонерів. 2020, том 18, № 1-2 
These results indicate that cereal grains have a pronounced antioxidant activity that should not be neglected. Recently, a lot attention has been paid to coloured wheat varieties (Mpofu et al., 2006). It was reported that coloured wheat varieties have high antioxidant capacity, and can absorb free radicals due to the content of phenols and anthocyanins (Li et al., 2005).

\section{Materials and methods}

Specimens of wheat (Triticum aestivum L.) cultivars with different colors, namely: Bilyava white grain (registration number 10006023), Kuyalnik - red grain (registration number 99007007), and Chernozerna - purple grain (ДРСР, 2019). Used specimens were grown on the experimental fields of the Institute of Plant Physiology and Genetics of the National Academy of Sciences of Ukraine, Kyiv region, Hlevakha village during 2018-2019 years. Wheat was milled using laboratory mill LM 3100 (Perten Instruments, Sweden) in the fine grinding of high uniformity mode, which improves the repeatability and reliability of analysis (ДСТУ, 2019) followed by storage in paper bags at room temperature until the end of the experiment. The first measurement was performed on the day of grinding the sample, each subsequent measurement after 8 days.

Sample preparation. Before each measurement, the contents of the paper bags were mixed, and repeats were weighed $0.1 \mathrm{~g}( \pm 3 \mathrm{mg})$, then transferred into a microtube with $1 \mathrm{ml}$ of $70 \%$ ethanol. The solution was incubated at room temperature in the dark for $30 \mathrm{~min}$ with periodic mixing to create emulsion. After incubation, the samples were centrifuged at $14.5 \times \mathrm{g}$ for $4 \mathrm{~min}$ to precipitate the milled grain components. The resulting solution was used to determine total antiradical activity.

Determination of antioxidant activity of extracts. Absorption activity of free radicals by alcoholic extracts of wheat with different grinding was determined using a spirituous solution of DPPH as a source of stable free radical. The principle of method is proposed by Blois in 1958 and later on described in our last publication (CaxHo et al., 2015). In general, DPPH alcohol solution has a dark purple colour and the absorption maximum at $520 \mathrm{~nm}$. During neutralization process it discolors or turns straw yellow. This property of DPPH allows us to visually monitor the neutralization reaction and calculate the initial activity of free radicals while reducing the intensity of absorption. DPPH was used as a solution in $96 \%$ ethyl alcohol (radical concentration $10^{-4} \mathrm{M}$ ). The reaction was performed in 96-wells microplates.

A mixture of the radical and an investigated extract in different concentrations was added into wells of microplate. The reaction mixture was kept at room temperature in the dark for $30 \mathrm{~min}$. Then optical density of mixture at a wavelength of $520 \mathrm{~nm}$ was measured using a microplate reader MR 700 (Dynatech Nevada, USA). In addition, optical density of extracts in alcohol (without the addition of DPPH) was measured. In calculations this value was subtracted from the absorption value of the reaction mixture. Quantification of free radical uptake was expressed as a percentage of inhibition. Further plotting of the DPPH inhibition values of staining on the mixture concentration was done followed by setting of extract concentration, which had caused $50 \%$ inhibition of free radical staining (EC50).

Statistical analysis. The average percent inhibition and standard deviation were determined from the data obtained (using the program Microsoft Office Excel 2010).

\section{Results and Discussion}

Results of the antioxidant activity of wheat grains with different colours and grinding rates are shown in Fig. 1-3.

As shown in Fig. 1, there is a decrease in $A O A$ in each and flour for white wheat with each subsequent measurement, which may indicate oxidation or destruction of substances with antioxidant activity. Thus, during the entire storage period the antioxidant activity of grist was decreased by $30 \%$ and antioxidant activity of flour was decreased by $53 \%$.

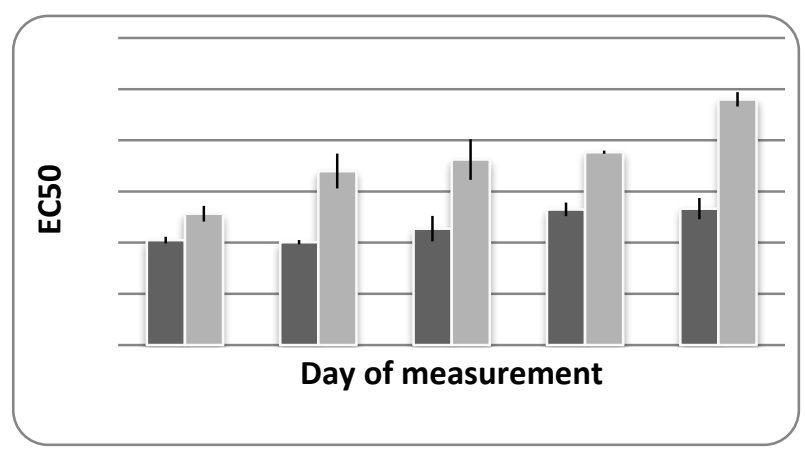

Fig. 1. Comparison of the arithmetic mean values of EC50 from white wheat «Bilyava» $\square$ Grist, $\square$ Flour. 
According to Fig. 2 for the flour and grist of red wheat, the decrease in antiradical activity was shown, which may also indicate the oxidation or destruction of substances with antioxidant activity. Thereby, the antioxidant activity of grist and flour decreased by $44 \%$ and $23 \%$ respectively. This may indicate the difference in quantitative and qualitative composition of the antioxidant substances in grains with different colours.

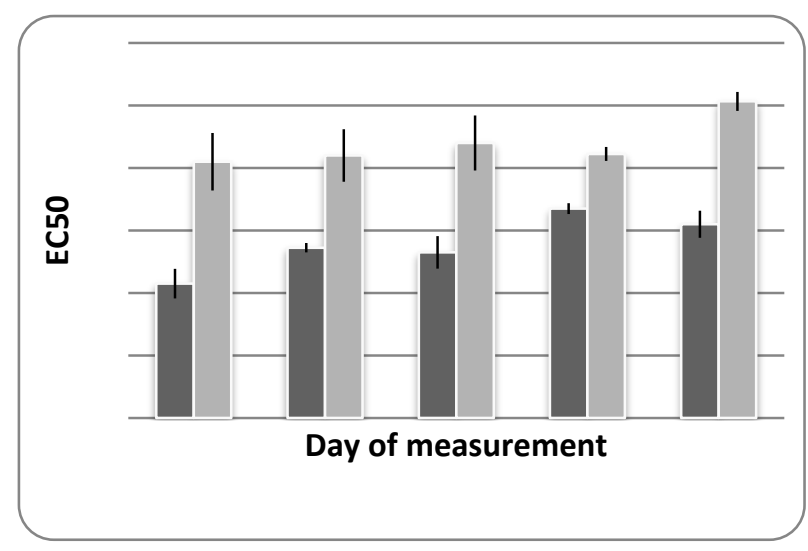

Fig. 2. Comparison of the arithmetic mean values of EC50 from red wheat «Kuyalnik» $\square$ Grist, $\square$ Flour.

As it is shown in Fig. 3, the decrease of AOA for flour and grist of purple grain was observed with each subsequent measurement. This may indicate oxidation or destruction of substances with antioxidant activity. Thus, antioxidant activity of the grist and flour declined by $48 \%$ and $24 \%$, respectively. The current results are very similar to the AOA dynamics offered by wheat grains.

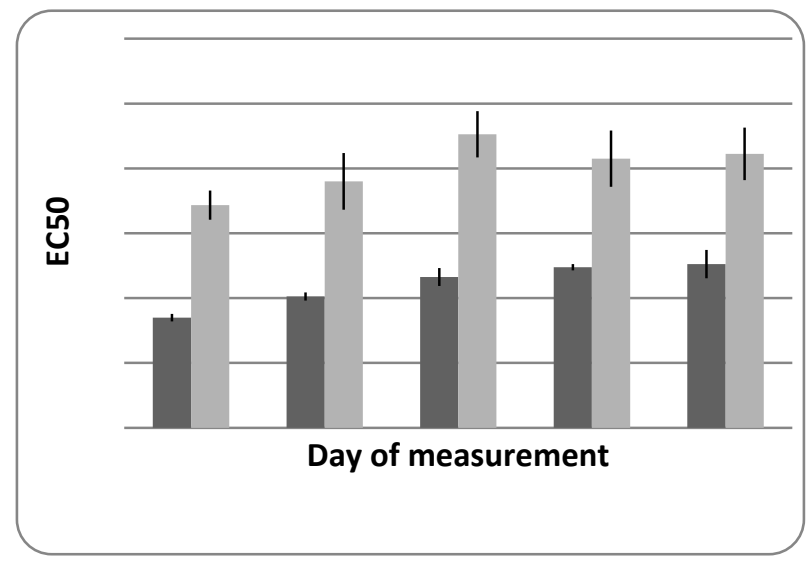

Fig. 3. Comparison of the arithmetic mean values of EC50 of purple grain «Chernozerna» $\square$ Grist, $\square$ Flour.
The highest values of antioxidant activity was observed in the Chernozerna grist at the beginning of the experiment and at the end of the storage period, which indicate the highest content of antioxidant substances in the Chernozerna cultivar possessing purple colored grain.

The highest values of antioxidant activity of flour extracts was observed in white wheat flour Bilyava at the beginning of the experiment, whereas after the long-term storage the maximum activity value was observed in purple flour Chernozerna.

The results obtained in this study showed that alcoholic wheat extract is an effective absorber of free radicals (Liu et al., 2010).

There is some disagreement as to the relationship among the total phenol content, antioxidant activity and grain colours (Kitts et al., 2000). Grain colour has been found not to be the only factor associated with the level of antioxidant substances, as shown by (Yaoguang et al., 2015).

Chernozerna belongs to wheat cultivars with black or purple seeds. Black wheat has become popular within a number of countries recently. (Zong et al., 2006) Reported that grains of blue, black, purple and violet wheat have significantly higher content of antioxidants than grains of white or red wheat. It was shown all coloured wheat cultivars had higher antioxidant activity than white wheat. These data correlate well with the finding we obtained.

Thus, in most measurements of grist, the antioxidant activity is higher in grains of the Chernozerna cultivar, which was similarly demonstrated by ( $\mathrm{Li}$ et al., 2003) for a different cultivar. Comparison of the arithmetic mean EC50 in flour showed no similar activity dependence on the colour of the grain - higher activity was found in flour from white wheat while the flour from Chernozerna grains had better characteristics after long-term storage.

It is known that most of the substances that can have a free radical-neutralization effect accumulate in the outer shell, the crushed parts of which are present in the grist. This may explain the higher activity of the coloured grain (Sang et al., 2002). Such substances can be flavonoids and phenolic compounds (anthocyanidins, flavonols, flavones, isoflavones, flavanones, flavanols, etc.), including colored anthocyanins (water-soluble pigments from the class of flavonoids) (Miller et al., 2000). 
Therefore, the antioxidant activity of white wheat flour may be mainly related to the content of ferulic and other phenolic acids, whereas in coloured wheat additional effect may be due to the anthocyanin content. Therefore, difference in antioxidant activity among cultivars of wheat may be due to the different quantitative and qualitative composition of the available compounds with antioxidant activity.

Comparison of EC50 for grist meal and grain of the same colour showed significantly higher antioxidant activity in the grist. To summarize, the asymmetric distribution of antioxidant components in wheat grain was observed - the concentration of bioactive components is higher in the outer layers of grain, while grist showed higher antioxidant activity. Thus, we cannot expect uniformity for grist and flour. The antioxidant activity may vary depending on the actual composition of these fractions and growing conditions, which has also been demonstrated by (Chandrika et al., 2008).

Therefore, the antioxidant activity of white wheat is mainly associated with phenolic acids, and in coloured wheat the obtained additional effect is due to the high content of anthocyanin. The content of phenolic acid in colored cultivars of wheat was much higher than that of white wheat, but there were no significant differences in the content of phenols among the studied wheat culti?vars of different colors. On the other hand, there was a certain trend in the content of anthocyanin, among different coloured wheat, most notably in the Chernozerna cultivar and the least in Bilyava cultivar.

\section{Conclusions}

The asymmetric distribution of antioxidant components was observed in wheat grains. The concentration of bioactive constituents was higher in the outer layers of grain and the grist fraction showed higher antioxidant activity than flour. The highest antioxidant activity was demonstrated by the grist meal of the Chernozerna cultivar, and the lowest - by the cultivar Bilyava. Immediately after grinding, the white wheat flour showed the greatest activity, but after long term storage, the purplegrain flour had better characteristics.

\section{References}

1. Blois M. S. Antioxidant determinations by the use of a stable free radical. Nature. 1958. Vol. 181. P. 1199-1200. doi: 10.1038/1811199a0.

2. Cook N. C., Samman S. Flavonoids - chemistry, metabolism, cardioprotective effects and dietary sources. Journal of Nutritional Biochemistry. 1996. Vol. 7. P. 66-76. doi: 10.1016/S0955-2863(95)00168-9.

3. Chandrika M., Liyana-Pathirana A, Fereidoon $S$. Antioxidant and free radical scavenging activities of whole wheat and milling fractions. J. Agric. Food Chem. 2008. Vol. 101(3). P. 1151-1157. doi: 10.1016/j.foodchem. 2006.03.016.

4. Kitts D. D., Wijewickreme A. N., Hu C. Antioxidant properties of North American ginseng extract. Mol. and Cell. Bioch. J. 2000. Vol. 203. P. 1-10.

5. Derzhavnyy reiestr sortiv roslyn, prydatnykh dlia poshyrennia v Ukraini stanom [Chynnyy vid 201912-18]. Vyd. ofits. Kyiv. Minekonomiky. / Державний реєстр сортів рослин, придатних для поширення в Україні [Чинний від 2019-12-18] Вид. офіц. Київ, Мінекономіки.

6. DSTU 3768:2019. Pshenytsia. Tekhnichni umovy. Vyd. ofits. Kyiv / ДСТУ 3768:2019. Пшениця. Технічні умови. Вид. офріц. Київ.

7. Liangli L., Perret J., Haris M., Wilson J., Haley S. Antioxidant properties of bran extracts from «Akron» wheat grown at different locations. J. Agric. Food Chem. 2003. Vol. 51. P. 1566-1570. doi: 10.1021/ jf020950z.

8. Li W. D., Shan F., Sun S. C., Corke H., Beta T. Free radical scavenging properties and phenolic content of Chinese black-grained wheat. J. Agric. Food Chem. 2005. Vol. 53. P. 8533-8536. doi: 10.1021/ jf051634y.

9. Liu Q., Qiu Y., Beta T. Comparison of antioxidant activities of different colored wheat grains and analysis of phenolic compounds. J. Agric. Food Chem. 2010. Vol. 58. P. 9235-9241. doi: 10.1021/ jf101700s.

10. Liyana-Pathirana C. M., Shahidi F. Antioxidant activity of commercial soft and hard wheat (Triticum aestivum L.) as affected by gastric $\mathrm{pH}$ conditions. J. Agric. Food Chem. 2005. Vol. 7. P. 2433-2440. doi: 10.1021/jf049320i.

11. Miller H. E., Rigelhof F., Marquart L., Prakash A., Kanter $M$. Antioxidant content of whole grain breakfast cereals, fruits and vegetables. Am. College of Nutrition. J. 2000. Vol. 19. P. 312S-319S. doi: 10.1080/07315724.2000.10718966.

12. Mpofu A, Sapirstein H. D., Beta T. Genotype and environmental variation in phenolic content, phenolic acid composition, and antioxidant activity of hard spring wheat. J. Agric. Food Chem. 2006. Vol. 54. P. 1265-1270. doi: 10.1021/jf052683d.

13. Merike V., Kersti M., Tuuli Li, Kati H. Phenolic compounds and the antioxidant activity of the bran, flour and whole grain of different wheat varieties. 
Procedia Chemistry. 2010. Vol. 2. P. 76-82. doi: 10.1016/j.proche.2009.12.013.

14. Polishchuk S. S., Kyrdohlo E. K., Mykhalska L. M., Morgun B .V., Pokhylko S. Y., Rybalka O. I., Schwartau V. V. Quantification of trace elements Fe, $\mathrm{Zn}, \mathrm{Mn}$, Se in barley grain. Agric. Science and Practice. J. 2016. Vol. 3(1). P. 49-54. doi: 10.15407/ agrisp3.01.049.

15. Rice-Evans C. A., Miller N. J., Papanga G. Antioxidant properties of phenolic compounds. Trends in Plant Science. J. 1997. Vol. 2. P. 152159. doi: 10.1016/S1360-1385(97)01018-2.

16. Sakhno L. O., Lystvan K. V., Kuchuk M. V. Antyoksydantna aktyvnist' lystkiv biotekhnolohichnoho ripaku (Brassica napus L.) zi stiykistiu do herbitsydiv na osnovi hlifosatu i hliufozynatu. Visnyk Kharkivs'koho natsional'noho ahrarnoho universytetu. 2015. Vol. 3. P. 62-70. [in Ukrainian] / Caxно Л. О., Листван К. В., Кучук М. В. Антиоксидантна активність листків біотехнологічного ріпаку (Brassica napus L.) зі стійкістю до гербіцидів на основі гліфосату і глюфозинату. Вісник Харківського національного аграрного університету. 2015. T. 3. C. $62-70$.

17. Sang S., Lapsley K., Jeong W. S., Lachance A. P., Ho C., Rosen R. T. Antioxidative phenolic compounds isolated from almond skins (Prunus amygdalus Batsch). J. Agric. Food Chem. 2002. Vol. 50. P. 2459-2463. doi: 10.1021/jf011533+.

18. Yaoguang L., Dongyun M., Dexiang S., Chenyang $W$. Total phenolic, flavonoid content, and antioxidant activity of flour, noodles, and steamed bread made from different colored wheat grains by three milling methods. The Crop J. 2015. Vol. 3. P. 328-334. doi: 10.1016/j.cj.2015.04.004.

19. Zong X. F., Zhang J. K., Li B. X., Yu G. D., Shi Y. M., Wang S. G. Relationship between antioxidant and grain colors of wheat (Triticum aestivum L.). Acta Agronomica Sinica. 2006. Vol. 32. P. 237-242.

Стаття надійшла до редакції 13.10.2020. Прийнята до друку 29.10.2020

\section{ЗМІНА АНТИОКСИДАНТНОÏ АКТИВНОСТІ ЗЕРНА ПШЕНИЦІ РІЗНОГО ЗАБАРВЛЕННЯ У ПРОЦЕСІ ЗБЕРІГАННЯ}

В. Б. Катрій ${ }^{1}$, К. В. Листван ${ }^{2}$, Б. В. Моргун ${ }^{1,2}$, Н. В. Сандецька', Великожон Л. Г.,

${ }^{1}$ Інститут фрізіології і генетики рослин НАН України Україна, 03022, м. Київ, вул. Васильківська, 31/17

${ }^{2}$ Інститут клітинної біології та генетичної інженерії НАН України Україна, 03143, м. Київ вул. Академіка Заболотного, 148 e-mail: katriy.vlad@gmail.com

Мета. Оцінити зміну антиоксидантої активності (AOA) у процесі зберігання борошна $i$ шроту, отриманих при помелі зерна пшениці різного забарвлення: білого, червоного та фріолетового на протязі місячного терміну зберігання. Зерно пшениці містить компоненти з антиоксидантною активністю. 3 часом АOА може змінюватись, тому важливо було дослідити динаміку зміни $A O A$ y зразках зерна пшениці різного помелу: борошно $i$ цільнозмелене зерно (шрот). Методи. Рівень антиоксидантної активності спиртових екстрактів борошна і шроту пшениці визначали на основі їх властивості нейтралізувати стабільні вільні радикали розчину 2,2-дифенііл-1-пірилгідразил (DPPH). Результати. Досліджено зміну антиоксидантної активності трьох різних сортів пшениці, а саме: Білява - біле зерно, Куяльник червоне та Чорнозерна - фріолетове зерно. Висновки. Був помічений асиметричний розподіл компонентів з антиоксидантними властивостями у зерні пшениці. Найвищу антиоксидантну активність продемонстрував сорт з фіолетовим зерном, найнижчу - сорт з білим зерном.

Ключові слова: кольорове зерно, антиоксидантна активність, борошно, шрот. 